\title{
Psychographic Insights from a Malaysia Tourism Industry
}

\author{
Noor Zatul Iffah Hussin ${ }^{1}$ \\ ${ }^{1}$ School of Maritime Business and Management, Universiti Malaysia Terengganu, Kuala Terengganu, Malaysia \\ Correspondence: Noor Zatul Iffah Hussin, School of Maritime Business and Management, Universiti Malaysia \\ Terengganu, 21030 Kuala Terengganu, Terengganu, Malaysia. Tel: 9-668-4864. E-mail: \\ zatul.iffah@umt.edu.my
}

Received: May 16, 2013 Accepted: June 12, 2014 Online Published: September 29, 2014

doi:10.5539/ass.v10n19p24 URL: http://dx.doi.org/10.5539/ass.v10n19p24

\begin{abstract}
An investigation of Malaysia tourism development was conducted to identify the psychographic character of travellers in each phase of development. Resulted from analysing the secondary data (obtained from government archives, local newspapers and journals) and informal conversation with the government experts revealed that from the First until the Fifth Plan, the Malaysia tourism industry appealed mostly to allocentric and near allocentric travellers. As the demand increase and destination development become more tourist-oriented, the destination attracted the mid-centric tourist (in Sixth to Seventh Plans). Finally, in the Eighth and Ninth Plans, it appealed more to the psychocentric tourist than the allocentric tourist. The results indicate qualified support for Plog's psycographic model within a country setting.
\end{abstract}

Keywords: Plog theory, segmentation, tourism area life cycle, Malaysia tourism

\section{Introduction}

The development of a destination for tourism is a dynamic process that evolves over time. Many scholars apply the concept of the 'life cycle model' to indicate the development of tourism from the perspective of evolution to explain the whole life cycle process of a destination.

One of the simplest models that applied the life cycle process was forwarded by Christaller (1993). The model pointed out that tourist locations follow a relatively consistent process of evolution starting from discovery, through to growth and decline (Meyer-Arendt, 1985). Gee, Makens, and Choy (1997) adapted a four -stage model of tourist activity comprising discovery, initiative and local response, institutionalisation and saturation and alienation. Plog (1974) delineated a life cycle from the perspective of the travelers' psychology and classified tourists into three types: the allocentric, the mid-centric, and the psychocentric (refer to Figure 1, Table 2 and Table 3). Butler advanced the ideas from Plog by recognizes the complex mix of tourist types in a destination area at any given time instead of a particular tourist at a particular period of development (France, 1991; Morais, Dong, \& Yang, 2006 ).

Plog (2001) asserted that 'at each stage, the destination appeal to different psychographic groups of travellers, determines the destination characteristic and success' (p. 18) (refer to Table 3 ). For instance, the psychocentric or dependable tourist is cautious, conservative, intellectually restricted, repressed and inward looking. The psychocentric or dependable tourist travels less frequent, prefers driving to flying and seeks familiar, well developed destination. By contrast, the allocentric or venturer is an extroverted, intellectually curious, confident individual who seeks variety and novelty when travelling, prefer to fly, travel interdependently and explore new areas before they become too 'touristy'. Finally, mid-centric sit between these two extremes and share elements of each to varying degree (refer Table 2) (McKercher, 2011). However, this was questioned on the grounds that Plog's psychographic model was more attuned to describe the market rather than predicting the life cycle stage, as destinations usually attract a diversity of tourists ranging from allocentric/venture to psychocentric/dependable (McKercher, 2011). Rather than predicting the life cycle, the Plog model could be used as a tool to assess how to make the destination more accessible to certain markets.

Notwithstanding criticisms the Plog model such as ineffective model as predictor of traveller behaviour (Litvin, 2006); and the impact of distance decay and culture distance have on the type of tourist who is willing to visit (McKercher, 2011), Plog's model is still used as psychographic profiling to predict the tourist life cycle as it is the most cited work in literature along the Butler's (1980) life cycle (McKercher, 2011; Siguaw, Enz, \& A, 2008; 
Weaver, 2012) and compare to others motivation models, Plog's model is simple and easily understood (Litvin, 2006).

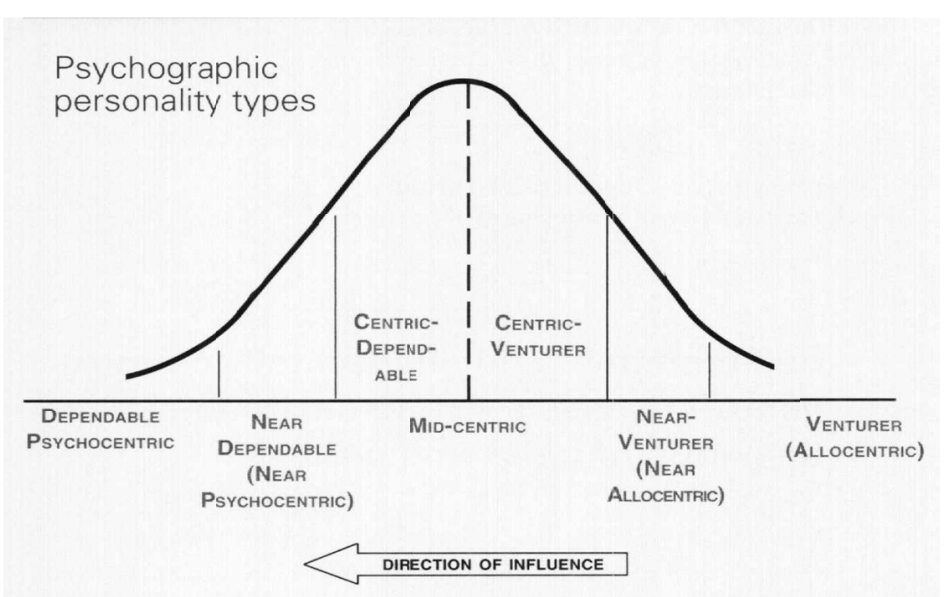

Figure 1. Psychographic Positions of Destinations (Adapted from Plog, 2001)

Having seen the Plog's model in predicting the evolution of destination, thus this study will discuss the applicable of these models from Malaysia perspective. As mentioned by Weaver (2012), venturers, centrics and dependables have been linked respectively with the exploration, development and saturation or decline stages of the tourism areas life cycle of Butler (refer Table 1).

Table 1. Psychographics predictors of destination life cycle

\begin{tabular}{lllll}
\hline Stage of Butler Tourist Lifecycle & Exploratory & Involvement & Development & Consolidation/ Stagnation \\
\hline Plog's Psycographic Model & Venturer & Near-Venturer & Mid-Centric* & Dependable \\
\hline
\end{tabular}

Source: Plog (1991) and *Cooper(1997)

Table 2. Allocentric and psychocentric travellers characteristic

\begin{tabular}{|c|c|}
\hline Psychocentric (Dependable) & Allocentric (Venturer) \\
\hline Travel less frequently & Travel more frequently \\
\hline Stay for shorter periods of time when travelling & Take relatively long trips \\
\hline Spend less per capita at the destination & Spend more each day per capita \\
\hline Prefer the familiar in travel destinations & Prefer non-touristy areas \\
\hline Like commonplace activities at travel destinations & $\begin{array}{l}\text { Enjoy sense of discovery and delight in new experiences, } \\
\text { before others have visited the area }\end{array}$ \\
\hline $\begin{array}{l}\text { Tend to select recreational activities at these destinations } \\
\text { that also are familiar }\end{array}$ & $\begin{array}{l}\text { Prefer to participate in local customs and habits and tend to } \\
\text { avoid those events that seem too common or familiar, or } \\
\text { those staged for tourists. }\end{array}$ \\
\hline Prefer sun ' $n$ ' fun sports, including considerable relaxation & Prefer novel and different destination \\
\hline $\begin{array}{l}\text { Purchase plenty of souvenirs, tee-shirts, decals, and other } \\
\text { strong visual reminders of where they have been }\end{array}$ & $\begin{array}{l}\text { Purchase mostly authentic local arts and craft, rather than } \\
\text { souvenirs. }\end{array}$ \\
\hline Are likely to return to a destination & $\begin{array}{l}\text { Tend to seek new destinations each year, rather than return } \\
\text { to previously visited places. }\end{array}$ \\
\hline Low activity level & High activity level \\
\hline Prefer destinations they can drive to & Prefer flying to destinations \\
\hline $\begin{array}{l}\text { Prefer heavy tourist accommodations, such as heavy hotel } \\
\text { development, family type restaurant, and tourist shops }\end{array}$ & $\begin{array}{l}\text { Tour accommodations should include adequate-to-good } \\
\text { hotels and food, not necessarily modern or chain-type hotels, } \\
\text { and few 'tourist' type attractions }\end{array}$ \\
\hline Prefer familiar atmosphere) & $\begin{array}{l}\text { Enjoy meeting and dealing with people from a strange or } \\
\text { foreign culture }\end{array}$ \\
\hline $\begin{array}{l}\text { Complete tour packaging appropriate, with heavy } \\
\text { scheduling of activities }\end{array}$ & $\begin{array}{l}\text { Tour arrangements should include basics (transport and } \\
\text { hotels) and allow considerable freedom and flexibility. }\end{array}$ \\
\hline
\end{tabular}

Source: Plog (1991) 
Identifying psychographic segmentation parameters allows tourism destinations to increase the effectiveness of their promotional campaigns by targeting the appropriate audience, focusing the message on actual segment needs, and selecting the appropriate media. It can also create a long- term, sustainable competitive advantage for a destination.

\section{Methodology}

The aim of the study is to recognise the psychographic group of travellers in each phase of Malaysia tourism development. As asserted by Plog (1974), McKercher (2011) and Zirulia (2013) each stage of destination appeals to different psychographic groups of travellers from Allocentrics and Psychocentrics, who determine the character and success. Given this, the characteristic of qualitative methods are considered eminently more suitable than those of quantitative. As qualitative is the root for interpretive paradigm, which recognises the significance of subjective experience and is characterised by greater depth, a research design include data gathering methods such as informal conversation with the government experts from the Ministry of Tourism and Tourism Malaysia, archival data and inductive content analysis will be best suit for this study.

\section{Plog's Applied to Malaysia Destination}

Different stages of Butler's TALC will appeal to different psychological groups of travellers. According to Plog (2001), in psychographic personality types as cited by Cooper (1997), Plog (2001) envisages that a destination could appeal to allocentrics in the early stages (exploratory and involvement), to mid-centrics in the development and to psychocentrics in the consolidation or stagnation stage. By understanding the psychographic curve, the destination planner can predict and control the development pattern to maintain an ideal market positioning (Plog, 2001).

Each destination development stage will be appeal to a different psychographic group of travellers. This does inexorably imply that from the First until the Fifth Plan, the Malaysia tourism industry appealed mostly to allocentric and near allocentric travellers. As the demand increase and destination development become more tourist-oriented, the destination attracted the mid-centric tourist (in Sixth to Seventh Plans). Finally, in the Eighth and Ninth Plans, it appealed more to the psychocentric tourist than the allocentric tourist.

The segmentation strategy used by the Department of Tourism in the exploratory stage (First Plan) was based on markets with the highest number of tourist arrivals. In other words, a geographic segmentation method was used. However, due to the inadequate data for this period, it was uncertain whether the department recognized the motivations of the target market and applied it in designing tourism products. Yet, based on the basic hotel development constructed according to international standards and general facilities concentrated in the four municipals areas, it can be concluded that the Department of Tourism did not differentiate its tourism product according to target market preferences except when it came to developing the infrastructure generally to the international tourists. Even though there was a lack of infrastructure to cater to foreign tourist demand, still foreign tourist arrivals increased from 23,225 in 1965 to 76,384 in 1970 (Economic Planning Unit, 1971). This results appear to mirror a remark already voiced by Plog (2001) that indicated, the segmentation market in the First Plan (venturers) was adventurous and required few support services (such as hotels and restaurants, organized sightseeing activities, or 'things to do'). Evidently, this also led to the conclusion that the tourist preferred novel destinations and enjoyed a sense of discovery, while also looking for the assurance of tour accommodation and arrangement (transport, hotel, food).

The organising of the PATA conference in early 1972 (Second Plan) has made TDC notice the importance of having a proper tourism planning (TDC, 1972). In comparison with previous plan, TDC started to organise several marketing activities directed to its market segment whith the highest inbound tourist arrivals: Europe, Australia, Japan, the Middle East and Southeast Asian countries (TDC, 1975). TDC also started to consider the motivation of its market segment when their needs and preferences were taken into account. The significance of nationality regarding travel motivation was consistent with other studies previously mentioned (Jonsson \& Devonish, 2008) (Pizam \& Sussmann, 1995).

Hsieh, O'Leary \& Morrison suggest that 'segmentation leads to a more efficient allocation of marketing resources and a more precise setting of market objectives. It can offer significant advantages as a competitive strategy and as a guide to market planning and promotional activities'(1992, p. 210). This study confirms the strategy utilized by TDC, where in order to design tourism products and manage its resources effectively either in a short-term or long-term marketing strategy, it is important to understand the why, where and what the target market. 
Considering the concentration on developing new tourism products and infrastructure that were tailored according to market segment needs and preferences (in the Third Plan until Fourth Plan) indicated that the tourist was motivated toward having a reasonable accommodation and infrastructure while visiting Malaysia. This was similar to the finding by Plog (2001) in comparison to the venturers (First Plan), the near venturers were not as adventurous. Thus, the government was responsible to develop more infrastructures to cater the near-venturers' demand since the private sector usually participated less in the early tourism industry. This statement affirm the fact that the 'government has to undertake an entrepreneurial role to ensure the pioneer activities are initiated' (Jenkins \& Henry, 1982, p. 501). This was similar to respondent 3 (Tourism Malaysia) who stated the government acts as a catalyst for tourism development. This idea was to demonstrate to the private sector the lucrative nature of the tourism industry.

With the need to use resources efficiently, the government began by concentrating on the West Coast areas yet not neglecting the East Coast areas. However, the infrastructure construction was still deficient in catering to tourist demand. Thus, local involvement in creating the local atmosphere and providing native crafts and local accommodation was enough to fulfil the venture and near-venture motivation curiosity about the local culture and people (Plog, 2001). As most of the Malaysian market segment was somewhat under the venture, tending to be more pragmatic and practical in selecting a destination, TDC's advertising strategy concentrated on print media and TV programme (film) with the nature, culture and friendly people attraction being highlighted. Indeed, this finding was similar to Plog (1974), where he investigated media patterns and selective purchase habits. Plog found that venturers tend to prefer print media and very selective in TV programmes with documentaries and TV specials often being their favourite.

A 30 per cent increase of international tourists visiting Malaysia during the Fourth Plan led TDC to become more structured in its segmentation strategy in the Fifth Plan (Economic Planning Unit, 1986). Besides, focusing on high tourist arrivals, expenditure and motivation, TDC acknowledged the importance of categorizing its international tourists into several factors such as awareness level, accessibility, government policies and desire to travel The identification of these variables enabled Malaysia to become more focused on promotional activities, enhancing infrastructure development (international and budgeted hotel standard and non-accommodation) and improved road and air transportation efficiency.

By the development stage (Sixth Plan), the previous (First Plan until Fifth Plan) market segment criteria was reassess and resulted to an identification of the purpose of travelling and type of tourist that come to each destination (respondent 4,Tourism Malaysia). As a result, eight specific attractions (food, history, culture, sun, fun sport and relaxation) at a given destinations (Tourism Malaysia, 1995) were developed to accommodate tourist needs and preferences (respondent 1, Ministry of Tourism.). The sun, fun sport and relaxation such as islands, beaches, and nature fit mid-centrics' motivation, whose personalities fall between the Venturers and Dependables (Weaver \& Lawton, 2000).

At the beginning of the Seventh Plan, Tourism Malaysia started to aggressively consider high-spender tourists as part of its segment. The cause of the selection was due to the lower or almost same number of foreign tourist receipts compared with other countries (Singapore, Thailand and Indonesia), even though their tourist arrival were lower than Malaysia's (Ministry of Tourism, 2004). However, the marketing strategy convened by Tourism Malaysia was unsuccessful as the implementation still revolved around mass tourism. As a result, from a list of the 'top tourism spenders in the world' released by UWTO, 7 out of 15 countries were selected as potential markets (United States, Germany, Japan, China, Republic of Korea, Sweden and Taiwan) (Ministry of Tourism, 2004). Besides these countries, Tourism Malaysia also considered Singapore, Indonesia, Australia, Scandinavia, Saudi Arabia, Hong Kong and Russia, as these countries contributed to high expenditures to Malaysia. The details of high-spending target markets' characteristics and preferences indicate that most tourists prefer a destination that has a high level of activity, is engaged in diversified cultures, activities or events and has both novel and sun/sport activities. Since Malaysia's destinations appeal mostly to the mid-centric market, TDC's objective to increase receipts was thus unsuccessful because mid-centric tourists will not spend as much as the allocentric yet more than the psychocentric tourist (Plog, 2001; Plog, 1974 \& Luostari,S. et al., 2013). This might be one of the reasons for the disaster in appealing to the top spender tourist (which are the venturers and near-venturers).

The penetration orientation toward high-spender tourists was continued in the Eighth Plan; however, the adaptation of the high quality and exclusive destination strategy is less accepted by the private sector, as their focus was still toward the mass tourism. The private's sectors noncooperation occurred due to an aggressive price competition with the competitors (Ministry of Tourism, 2004) as the product offered was generic in nature (comprising tourism products similar to those of neighbouring countries. This would be similar to Ladkin and 
Bertramini's (2002), who indicated that the private sector had not fully shared the same vision of tourism development or its benefits with Tourism Malaysia. This statement was then confirmed by respondent 5 (Tourism Malaysia) who explained that 'even though TDC's strategy concentrated on high spenders, it did not mean that the tourism package offered by the private sector had to concentrate only on this market. They could sell their tour package to other markets (low and medium spenders) as well'. This, could contributed to the failure of achieving the 'value for money' and high quality strategy. Evidently, this led to an unsustainable industry as Malaysia slowly moves toward the psychocentrics /dependable market that spend less per capita on a daily basis, prefer having a complete tour packaging and a familiar atmosphere. As verified by Plog (1974), a 'destination that attracting more Mid-Centric to Psychocentric audiences will have a struggle in the future' (p.58) as they less in spending, travelling and night of stay.

In addition to sustain the industry, by the Ninth Plan, Tourism Malaysia has introduced a new tourism product that is attuned to a broad and larger segment of tourists (who travel and spend more) while maintaining the old product (attractive tourism packages, hassle-free travel and upgraded transport infrastructure). Other activities to attract tourist include the inaugural 1Malaysia Contemporary Art Tourism (MCAT), a three month event, aimed at attracting high-spending tourists and Fabulous Food 1 Malaysia to display variety local foods. This strategy might capture the allocentric individual that spends more than the mid-centric and psychocentric individuals. As for promotion strategy, Tourism Malaysia has focused on both print and electronic media and the usage of websites, Flickr, Youtube and Facebook, which cater to both types of psychographic groups.

\section{Conclusion}

This study basically supports the relevance of Plog's psychographic models for predicting travel preferences, intention and aspiration such as the type of products they prefer and places they like to visit. This creates a better planning, management and marketing strategy that appeal to target prospects and travel experience. Since Malaysia tourism development is consistent with psychographic concept, it is possible for Malaysia to control or maintain development from approaching the decline stage and avoid becoming uncompetitive.

\section{Acknowledgements}

The author would like to thank Ministry of Tourism Malaysia and Tourism Malaysia for their full cooperation and insight of the topic.

\section{References}

Butler, R. W. (1980). The Concept of a Tourist Area Cycle of Evolution: Implications for Management of Resources. The Canadian Geographer, 24(1), 5-12. http://dx.doi.org/10.1111/j.1541-0064.1980.tb00970.x

Cooper, C. (1997). The Contribution of Life Cycle Analysis and Strategic Planning to Sustainable Tourism. In S. Wahab, \& J. J. Pigram (Eds.), Tourism, Development and Growth: The Challenge of Sustainability (pp. 78-94). New York: Routledge.

Economic Planning Unit. (1971). 2nd Malaysia Plan 1971-1975. Percetakan Nasional Malaysia Berhad.

Economic Planning Unit. (1986). 5th Malaysia Plan 1986-1990. Percetakan Nasional Malaysia Berhad.

France, L. (1991). An Application of the Tourism Destination Area Life Cycle to Barbados. Tourism Review, 46(3), 25-31.

Hsieh, S., O'Leary, J. T., \& Morrison, A. M. (1992). Segmenting International Travel Market by Activity. Tourism Management, 13(2), 209-223. http://dx.doi.org/10.1016/0261-5177(92)90062-C

Jenkins, C. L., \& Henry, B. M. (1982). Government Involvement in Tourism in Developing Countries. Annal of Tourism Research, 9(4), 499-521. Retrieved from http://www.sciencedirect.com/science/article/pii/ 0160738382900706

Jonsson, C., \& Devonish, D. (2008). Does Nationality, Gender, and Age Affect Travel Motivation? A Case of Visitors to The Caribbean Island of Barbados. Journal of Travel \& Tourism Marketing, 25(3-4), 398-408. http://dx.doi.org/10.1080/10548400802508499

Ladkin, A., \& Bertramini, A. M. (2002). Collaborative Tourism Planning: A Case Study of Cusco, Peru. Current Issues in Tourism, 5(2), 71-93. http://dx.doi.org/10.1080/13683500208667909

Litvin, S. W. (2006). Revisiting Plog's Model of Allocentricity and Psychocentricity..One More Time. Cornell Hotel and Restaurant Administration Quarterly, 47(3), 245-253. http://dx.doi.org/10.1177/001088040 6289138

Luostari, S., \& Bukenya, B. (2013). Problem faced by a New Destination when Trying to Establish Position 
within Tourism market: Case: Destination Uganda.

McKercher, B. (2011). Are Psychographics Predictors of Destination Life Cycles? Journal of Travel \& Tourism Marketing, 19(1), 49-55. http://dx.doi.org/10.1300/J073v19n01_05

Meyer-Arendt, K. J. (1985). The Grand Isle,Lousiana Resort Cycle. Annals of Tourism Research, 12(3), 449-465. http://dx.doi.org/10.1016/0160-7383(85)90009-X

Ministry of Tourism. (2004). Review of the National Tourism Policy.

Morais, D. B., Dong, E., \& Yang, G. (2006). The ethnic tourism expansion cycle: The case of Yunnan province, China. Asia Pacific Journal of Tourism Research, 11(2), 189-204. http://dx.doi.org/10.1080/ 10941660600727616

Pizam, A., \& Sussmann, S. (1995). Does Nationality Affect Tourist Behavior. Annals of Tourism Reseach, 22(4), 901-917. http://dx.doi.org/10.1016/0160-7383(95)00023-5

Plog, S. C. (1974). Why Destination Areas Rise and Fall in Popularity. Cornell Hotel and Restaurant Administration Quarterly, 14(February), 55-58. http://dx.doi.org/10.1177/001088047401400409

Plog, S. C. (1991). Leisure Travel. Making it a Growth Market Again! New York: John Wiley.

Plog, S. C. (2001). Why Destination Areas Rise and Fall in Popularity. Cornell Hotel and Restaurant Administration Quarterly, 42(3), 13-24. http://dx.doi.org/10.1016/S0010-8804(01)81020-X

Siguaw, L. Z., Enz, J. A., \& A, C. (2008). Using Tourist Travel Habits and Preferences to Access Strategic Destination Positioning the Case of Costa Rica. Cornell Hospitality Quarterly, 49(3), 258-281. Retrieved from http://cqx.sagepub.com/content/49/3/258.short

TDC. (1972). Review of Activities Jan-July 1972. Kuala Lumpur: Research and Training Division.

TDC. (1975). Annual Report 1975. Kuala Lumpur: Research and Training Division.

Tourism Malaysia. (1995). Annual Report 1995. Kuala Lumpur: Research Division.

Weaver, D., \& Lawton, L. (2000). Tourism Management. Brisbane: John Wiley \& Son Australia. Ltd.

Weaver, D. B. (2012). Psychographic Insight from South Carolina Protected Area. Tourism Management, 33, 371-379. http://dx.doi.org/10.1016/j.tourman.2011.04.006

Zirulia, L. (2013). The Flying Dutchmen: Recent Trends in International Tourism from the Netherlands (No. 35 13). Retrieved from http://ideas.repec.org/p/rim/rimwps/35_13.html

\section{Copyrights}

Copyright for this article is retained by the author(s), with first publication rights granted to the journal.

This is an open-access article distributed under the terms and conditions of the Creative Commons Attribution license (http://creativecommons.org/licenses/by/3.0/). 